\title{
Induksi Partenokarpi dengan Ga3 pada Mentimun (Cucumis sativus L.) Lokal Madura
}

\author{
Induction of Parthenocarpy with Ga3 on Local Madura Cucumber (Cucumis sativus L.) \\ Suhartono $^{1 *}$, Ahmad Arsyadmunir ${ }^{1}$, Ismi Zahrotul Firdaus ${ }^{1}$ \\ ${ }^{1}$ Program Studi Agroekoteknologi, Fakultas Pertanian, Universitas Trunojoyo Madura \\ Jl. Raya Telang PO BOX 2 Kamal, Bangkalan, Jawa Timur, Indonesia, 69162 \\ *Email korespondensi: hartono_unijoyo@yahoo.co.id
}

Diterima: 07 Januari 2020 / Disetujui: 18 Maret 2020

\begin{abstract}
Cucumber (Cucumis sativus L.) is a type of vegetable that is very popular in the community where the fruit is sold in fresh as vegetables, pickles, and industrial raw materials (cosmetics and medicines). However, the very high content of seeds makes the processing less efficient. One technique for producing seedless fruit is parthenocarpy through phytohormone control. One of the hormones that can help induce parthenocarpy is gibberellins (GA3). This study aims to determine the effect of the application of various concentrations of the hormone gibberellins (GA3) on fruit formation and fruit quality in parthenocarpy of the Sumenep local cucumber. The study was conducted in the University Farm and Agrotechnology Laboratory, Faculty of Agriculture, University of Trunojoyo Madura, in December 2017 - March 2018. The study design used a Randomized Block Design (RCBD) with one treatment factor, namely gibberelline concentration of 0, 75, 150, 225, 300, and 375 ppm. The parameters observed included the number of female flowers, the percentage of success of the fruit becoming fruit, fruit weight, fruit diameter, fruit length, fruit thickness, number of seeds, fruit moisture content, and fruit texture. The results showed that the treatment of gibberelline hormone concentration did not have a significant effect on all parameters except the percentage of success of the fruit becoming fruit, the thickness of the fruit flesh, and the number of seeds that gave a real effect. The best concentration is 300 ppm which produces fruits with $81.5 \%$ fewer seeds and fruit thickness $16.9 \%$ thicker than polluted fruit. The number of seeds and giberilim concentration formed a linear regression equation y equal $345.67-0.92 \times$ with R2 is 0.90 .
\end{abstract}

Keywords: cucumber, giberelin, partenocarpy.

\section{$\operatorname{ABSTRAK}$}

Tanaman mentimun (Cucumis sativus L.) merupakan jenis sayuran yang sangat populer di masyarakat yang buahnya dijual dalam bentuk segar yaitu untuk lalapan, asinan, acar, dan bahan baku industri (kosmetik dan obat-obatan). Namun kandungan bijinya yang sangat banyak membuat proses pengolahan menjadi kurang efisien. Salah satu teknik untuk menghasilkan buah tanpa biji adalah secara partenokarpi melalui pengendalian fitohormon. Hormon yang dapat membantu induksi partenokarpi salah satunya adalah giberelin (GA3). Penelitian ini bertujuan untuk mengetahui pengaruh aplikasi berbagai konsentrasi hormon giberelin (GA3) terhadap pembentukan buah dan kualitas buah secara partenokarpi tanaman mentimun lokal Sumenep. Penelitian dilakukan di Kebun Percobaan dan Laboratorium Agroteknologi Fakultas Pertanian Universitas Trunojoyo Madura, pada bulan Desember 2017 - Maret 2018. Rancangan penelitian menggunakan Rancangan Acak Kelompok (RAK) dengan satu faktor perlakuan, yaitu konsentrasi hormon giberelin 0, 75, 150, 225, 300, dan 375 ppm. Parameter yang diamati meliputi jumlah bunga betina, persentase keberhasilan bunga jadi buah, bobot buah, diameter buah, panjang buah, ketebalan daging buah, jumlah biji, kadar air buah, dan tekstur buah. Hasil penelitian menunjukkan bahwa perlakuan konsentrasi hormon giberelin tidak memberikan pengaruh yang nyata terhadap semua parameter kecuali persentase keberhasilan bunga jadi buah, ketebalan daging buah, dan jumah biji yang memberikan pengaruh yang nyata. Konsentrasi terbaik adalah 300 ppm yang menghasilkan buah dengan jumlah biji 81,5\% lebih sedikit dan ketebalan daging buah 16,9\% lebih tebal daripada buah hasil polinasi. Jumlah biji dan konsentrasi giberilim membentuk persamaan regresi linier y sama dengan $345.67-0.92 \times$ dengan $R^{2}$ adalah 0.90 .

Kata kunci: giberelin, mentimun, partenokarpi. 


\section{PENDAHULUAN}

Mentimun merupakan sayuran yang sangat populer dan digemari oleh hampir seluruh masyarakat di Indonesia. Buah mentimun memiliki nilai gizi yang cukup baik karena sayuran buah ini merupakan sumber mineral dan vitamin (Sumpena, 2001). Tanaman mentimun dapat dibudidayakan dari mulai dataran rendah sampai dataran tinggi. Berbagai jenis lahan, seperti lahan sawah, lahan kering atau tegalan, dan lahan gambut dapat ditanami jenis sayuran ini. Mentimun menjadi salah satu pilihan komoditas usaha tani karena penanganan jenis sayuran ini relatif mudah, murah, dan berumur pendek apabila dibandingkan dengan tomat, cabai, atau terong.

Banyak jenis mentimun yang telah ditanam oleh petani salah satunya mentimun lokal Sumenep dengan luasan areal tanam $121 \mathrm{Ha}$ dan jumlah produksi 7,9 ton (Badan Puat Statistik, 2012). Pasar ekspor, misalnya Jepang, memiliki kriteria khusus untuk jenis mentimun yang di ekspor yaitu mentimun tanpa biji (Rukmana, 2010). Umumnya sayur buah ini dikonsumsi dalam bentuk segar maupun olahan seperti acara, asinan, bahkan untuk bahan kosmetika dan obatobatan (Sumpena, 2001).

Hingga saat ini, mentimun yang ada di pasaran adalah jenis mentimun yang memiliki biji. Namun dalam pengolahan menjadi bahan makanan, bahan dasar kosmetika serta obatobatan, biji buah akan di buang. Hal tersebut tentu saja kurang efisien. Selain itu, menurut Pandolfini (2009) bahwa tidak adanya biji dalam buah banyak disukai oleh konsumen karena dapat meningkatkan kualitas buah dan umur simpan buah. Salah satu metode untuk menghasilkan buah tanpa biji adalah melalui penyerbukan dan pembuahan secara mandiri yang dikendalikan melalui fitohormon.

Gejala pembentukan buah tanpa melalui proses polinasi dan fertilisasi disebut dengan partenokarpi dan buah yang dihasilkan dapat tidak memiliki biji. Partenokarpi lebih bermanfaat bagi peningkatan kualitas dan produksi buah, khususnya pada jenis tanaman komersil (hortikultura). Partenokarpi buatan dapat diinduksi melalui aplikasi zat pengatur tumbuh (Wijayanto et al., 2012). Salah satu hormon yang dapat digunakan untuk pembentukan buah secara partenokarpi adalah giberelin.

Giberelin mengendalikan pemanjang-an batang dan mengatur proses reproduksi pada tumbuhan (Widyati, 2016). Sedangkan menurut Suswanto (2002), giberelin merupakan salah satu ZPT yang umum digunakan untuk menghasilkan pertumbuhan buah tanpa biji yang banyak digunakan oleh produsen anggur tanpa biji dari kultivarkultivar anggur berbiji. Hal ini karena adanya gangguan pertumbuhan tabung sari sebelum pembuahan.

Berdasarkan penelitian Wulandari et al. (2014), pemberian giberelin tebukti berpengaruh terhadap peningkatan bobot buah mentimun varietas Mercy hingga lebih dari dua kali lipat dan dapat menurunkan jumlah biji hingga 50\% pada konsentrasi giberelin 200 ppm. Selain itu, biji yang dihasilkan lebih lunak dan daging buah semakin tebal. Selain itu pada penelitian Wijayanto et al. (2012) menunjukkan bahwa aplikasi GA3 dapat meningkatkan hasil dan kualitas buah pada semangka, berat segar buah, diameter buah dan jumlah biji buah semangka.

Berdasarkan beberapa hal di atas maka perlu dilakukan penelitian mengenai pengaruh pemberian hormon giberelin (GA3) untuk menginduksi pembentukan buah secara partenokarpi pada tanaman mentimun (Cucumis sativus L.) lokal Sumenep pada peningkatan kualitas buah dan dalam menghasilkan buah tanpa biji

\section{METODE PENELITIAN}

Penelitian ini dilaksanakan di Kebun Percobaan Agroteknologi Fakultas Pertanian Universitas Trunojoyo Madura pada bulan Desember 2017 - Maret 2018. Alat yang digunakan dalam penelitian ini antara lain timbangan analitik, texture profil analyzer, ember, cangkul, gunting pangkas, botol plastik, gelas ukur, pipet volume, labu ukur, cangkul, kamera, jangka sorong, nampan, penggaris, serta alat tulis menulis.

Bahan yang digunakan dalam penelitian ini antara lain benih mentimun lokal Sumenep yang didapat dari petani di Kabupaten Sumenep, pupuk anorganik (Urea, TSP dan $\mathrm{KCl}$ ), pupuk kandang, aquades, alkohol 96\%, giberelin 10\%, pestisida, kertas minyak, bambu, benang wol, kertas label, dan plastik parasut.

Penelitian ini menggunakan Rancangan Acak Kelompok (RAK) yang terdiri dari 6 konsentrasi perlakuan hormone giberelin dengan 4 ulangan. Perlakuan antara lain G0 (kontrol), G1 (75 ppm), G2 (150 ppm), G3 (225 ppm), G4 (300 ppm), dan G5 (375 ppm). Pelaksanaan penelitian terdiri dari penye-maian benih pada media campuran tanah dan pupuk kompos dengan perbandingan 2:1. Penyemaian benih dilakukan selama 10 hari dengan ciri bibit memiliki 3 helai daun. Bibit yang telah berumur 10 hari kemudian dipindahkan pada lahan yang telah diolah dan dicampur dengan pupuk kandang dengan dosis 10 ton/ha satu minggu sebelum transplanting (Sumpena, 2001). Pemeliha-raan meliputi penyulaman, pemasangan ajir, pengairan, dan penyiangan. Pemupukan dilakukan dengan pupuk anorganik (Urea $447 \mathrm{~kg} / \mathrm{ha}$, TSP $100 \mathrm{~kg} / \mathrm{ha}$ dan $\mathrm{KCl} 100 \mathrm{~kg} / \mathrm{ha}$ ) pada umur tanam 5, 15, dan 30 HST.

Aplikasi perlakuan dilakukan dengan cara mencelup bunga betina pada larutan hormon giberelin, tanaman pada lokal kontrol dilakukan selfing dan dilakukan pada pagi hari yaitu antara jam 5-6. Hal ini dilakukan karena aplikasi hormon pada tanaman tidak boleh terpapar sinar matahari secara langsung. Setelah bunga dicelupkan pada hormon giberelin, bunga ditutup menggunakan kertas minyak agar tidak terkontaminasi oleh serangga dan diberi label berisi tanggal untuk memudahkan aplikasi kedua. Pemberian hormon giberelin dilakukan sebanyak 2 kali yaitu pada awal pembungaan dan 24 jam setelah aplikasi pertama. Selanjutnya panen dilakukan pada buah umur 7 hari setelah aplikasi hormon maupun polinasi (kontrol).

Pengamatan dilakukan terhadap jumlah bunga betina, persentase keberhasilan bunga jadi buah, bobot buah, diameter buah, panjang buah, ketebalan daging buah, jumlah biji, kadar air, dan tekstur buah. Data hasil pengamatan dianalisis dengan analisis sidik ragam dan diuji lanjut menggunakan uji lanjut Duncan dengan taraf kesalahan 5\%. 


\section{HASIL DAN PEMBAHASAN}

Berdasarkan hasil penelitian, aplikasi berbagai konsentrasi hormon giberelin (GA3) tidak berpengaruh nyata terhadap jumlah bunga betina, bobot buah, panjang buah, diameter buah, kadar air, dan tekstur buah. Namun berpengaruh nyata terhadap parameter persentase keberhasilan bunga jadi buah, ketebalan daging buah dan jumlah biji.

Aplikasi hormon giberelin pada bunga betina yang mulai muncul pada bulan Februari dimana kondisi cuaca saat itu musim penghujan dengan curah hujan yang cukup tinggi. Hal ini menjadi salah satu factor keberhasilan pembentukan buah parteno-karpi. Selain itu faktor lain yang berpengaruh adalah tingkat kepekatan larutan, kelembaban dalam pembungkusan, dan sistem respon tanaman. Dapat dilihat pada Tabel 1 bahwa keberhasilan buah tertinggi diperoleh pada perlakuan G0 yang mana buah yang terbentuk adalah hasil dari polinasi. Sedangkan keberhasilan pembentukan buah partenokarpi tertinggi pada konsentrasi 350 ppm (G5). Pengaruh aplikasi hormone secara eksogen memberikan respon yang berbeda pada setiap tanaman dan bagian tanaman.

Sistem respons suatu bagian tanaman harus memiliki 3 bagian utama yaitu hormon harus ada dalam jumlah yang cukup di sel yang tepat, hormon harus dikenali dan diikat erat oleh setiap kelompok sel yang tanggap terhadap hormon (sel sasaran), dan protein penerima harus menyebabkan metabolik lain yang mengarah pada penguatan isyarat atau kurir hormon (Salisbury dan Ross, 1995).

Asam giberelat atau giberelin adalah kelompok besar asam karboksilat diterpenoid yang mempunyai kemampuan khusus memacu pertumbuhan tumbuhan utuh pada banyak spesies (Griffiths et al., 2006). Beberapa proses fisiologis tumbuhan yang dipengaruhi oleh giberelin adalah merangsang pemanjangan batang dengan merangsang pembelahan sel, merangsang pembungaan, memacu perkecambahan biji dorman, merangsang produksi enzim (a- amilase) dalam perkecambahan tanaman sereal untuk mobilisasi cadangan benih, dan dapat menyebabkan pembentukan dan perkembangan buah secara partenokarpi (Salisbury dan Ross, 1995). Secara normal, perkembangan buah terjadi setelah fertilisasi. Bertambahnya ukuran buah disebabkan oleh adanya 2 proses yaitu pembelahan sel dan pembesaran sel selanjutnya (Pardal, 2001).

Berdasarkan Tabel 2 bahwa aplikasi berbagai konsentrasi hormon giberelin tidak memberikan pengaruh nyata terhadap 3 parameter yaitu bobot buah, diameter buah dan panjang buah. Rerata bobot buah pada buah hasil partenokarpi cenderung lebih kecil dibandingkan dengan buah pada kontrol. Hal ini terjadi karena buah hasil fertilisasi memiliki biji yang lebih banyak sehingga suplai hormon dalam pembelahan dan pembentangan sel semakin besar dan berkurangnya jumlah biji diduga membuat bobot buah cenderung lebih kecil.

Tabel 1. Rerata jumlah bunga betina (buah) dan persentase keberhasilan bunga jadi buah per tanaman (\%)

\begin{tabular}{ccc}
\hline Perlakuan & Jumlah Bunga Betina & Persentase Keberhasilan Bunga Jadi Buah \\
\hline G0 & 6,13 & $92 \mathrm{f}$ \\
G1 & 6,19 & $31 \mathrm{a}$ \\
G2 & 6,25 & $45 \mathrm{~d}$ \\
G3 & 6,11 & $41 \mathrm{c}$ \\
G4 & 5,76 & $36 \mathrm{~b}$ \\
G5 & 5,04 & $56 \mathrm{e}$ \\
\hline BJND 5\% & ns & $*$
\end{tabular}

Tabel 2. Rerata bobot buah $(\mathrm{g})$, diameter buah $(\mathrm{cm})$, panjang buah $(\mathrm{cm})$, ketebalan daging buah, dan jumlah biji per tanaman (buah) akibat aplikasi hormon giberelin (GA3)

\begin{tabular}{|c|c|c|c|c|c|c|c|}
\hline \multirow{2}{*}{$\begin{array}{c}\text { Perlakuan } \\
\text { G0 }\end{array}$} & \multirow{2}{*}{$\frac{\text { Bobot Buah }(\mathrm{g})}{381,85}$} & \multirow{2}{*}{$\begin{array}{c}\begin{array}{c}\text { Diameter } \\
\text { Buah }(\mathrm{cm})\end{array} \\
5,38\end{array}$} & \multirow{2}{*}{$\begin{array}{c}\begin{array}{c}\text { Panjang } \\
\text { Buah }(\mathrm{cm})\end{array} \\
20,66\end{array}$} & \multicolumn{2}{|c|}{$\begin{array}{l}\text { Ketebalan Daging } \\
\text { Buah }(\mathrm{cm})\end{array}$} & \multicolumn{2}{|c|}{$\begin{array}{c}\text { Jumlah Biji per Tanaman } \\
\text { (buah) }\end{array}$} \\
\hline & & & & 1,42 & $\mathrm{a}$ & 410,48 & $\mathrm{e}$ \\
\hline G1 & 357,59 & 5,41 & 20,81 & 1,63 & $\mathrm{~b}$ & 240,17 & d \\
\hline $\mathrm{G} 2$ & 349,57 & 5,31 & 20,13 & 1,69 & $\mathrm{~b}$ & 161,92 & $\mathrm{c}$ \\
\hline G3 & 358,79 & 5,22 & 21,06 & 1,64 & $\mathrm{~b}$ & 114,40 & b \\
\hline G4 & 354,57 & 5,10 & 21,70 & 1,70 & $\mathrm{~b}$ & 76,62 & $a b$ \\
\hline G5 & 343,92 & 5,04 & 20,35 & 1,66 & $\mathrm{~b}$ & 33,48 & $\mathrm{a}$ \\
\hline BJND 5\% & ns & ns & ns & & & & \\
\hline
\end{tabular}


Selain itu, bentuk buah dan adanya rongga pada lapisan endokarpi buah hasil partenokarpi juga diduga membuat bobot buah cenderung lebih kecil. Serrani et al. (2007) mengungkapkan bahwa buah hasil induksi giberelin memiliki ukuran buah yang lebih kecil dibandingkan dengan buah berbiji. Hal ini disebabkan buah hasil partenokarpi dengan induksi giberelin memiliki jumlah sel yang lebih sedikit dibandingkan dengan buah hasil polinasi, meskipun ukuran sel hasil perlakuan giberelin lebih besar.

Diameter buah dan panjang buah juga cenderung lebih kecil dibandingkan dengan kontrol. Ini terjadi karena pada buah mentimun lokal Sumenep hasil partenokarpi, pada salah satu lapisan perikarpi (endokarpi) mengalami penurunan diameter dikarenakan biji yang berada didalam lapisan tersebut telah terhambat perkembangannya, sehingga penurunan diameter endokarpi menyebabkan diameter buah juga mengalami penurunan. Begitu pula dengan hasil panjang buah yang menunjukkan angka tidak berbeda jauh antara kontrol dengan perlakuan berbagai konsentrasi hormon giberelin tersebut. Panjang buah meningkat dari $20,66 \mathrm{~cm}$ pada kontrol menjadi $21,7 \mathrm{~cm}$ pada perlakuan konsentrasi 300 ppm,

Widodo (2002) mengungkapkan bahwa buah yang diberi perlakuan zat pengatur tumbuh (ZPT) secara eksogen kurang mencapai ukuran buah yang maksimal karena keberadaan biji dalam menstimulasi pertumbuhan buah tergantikan oleh ZPT. Zulkarnain (2010) menjelaskan bahwa hormon yang dominan berperan dalam perkembangan buah adalah hormon auksin dan giberelin. Auksin dan giberelin berperan dalam pembelahan sel dan kadar kadua hormon tersebut meningkat seiring dengan pertumbuhan biji dalam buah. Namun dalam pembentukan buah secara partenokarpi kadar auksin dan giberelin akan menurun tajam karena biji berhenti tumbuh dan memasuki periode pematangan. Jadi dengan pemberian giberelin secara eksogen dapat membantu proses pematangan dan pertumbuhan endosperm maupun embrio, dimana biji sebagai pensuplai ZPT bagi pertumbuhan dan perkembangan bakal buah. Perkembangan buah akan tetap terjadi dengan penambahan giberelin eksogen tetapi juga terjadi penghambatan pertumbuhan embrio sehingga biji tidak terbentuk.

Berdasarkan hasil penelitian, ketebalan daging buah hasil partenokarpi lebih besar dibandingkan dengan buah hasil polinasi. Hal ini sejalan dengan hasil penelitian Serrani et al. (2007) yang menyatakan bahwa perikarp buah hasil induksi GA3 lebih tebal dari buah hasil polinasi. Hormon giberelin yang diberikan secara eksogen dapat menginduksi terjadinya pembelahan sel dan pembentangan pada lapisan perikarpi di bakal buah (Salisbury dan Ross, 1995). Hal ini menyebabkan ukuran sel pada salah satu lapisan perikarpi semakin membesar. Lapisan perikarpi terdiri dari tiga lapisan, yaitu eksokarpi yang akan berkembang menjadi kulit buah, mesokarpi yang mengalami pembelahan dan pembentangan akibat induksi giberelin membentuk daging buah, dan endokarpi yang merupakan lapisan terdalam (Wulandari et al., 2014).

Giberelin juga mempengaruhi pemben-tukan jumlah plasenta buah dimana berdasarkan Gambar 1, buah hasil parteno-karpi menghasilkan jumlah plasenta buah yang lebih banyak daripada buah hasil polinasi. Pada kondisi normal, buah menti-mun memiliki 3 plasenta buah, namun pada buah hasil partenokarpi memiliki 4 sampai 5 plasenta buah. Hasil penelitian ini sama dengan hasil penelitian Setiawan et al. (2015), bahwa buah hasil partenokarpi induksi hormone giberelin mampu meningkatkan jumlah lokul pada tanaman tomat. Hal ini disebabkan karena giberelin mampu menekan ekspresi gen fasciated yang mengendalikan jumlah lokul. Cong et al. (2008) menambahkan bahwa fasciated mengendalikan jumlah karpel selama perkembangan bunga dan buah tomat. Hal ini sesuai dengan Liu dan Li (2012) yang menyatakan bahwa setiap genotipe memiliki respon yang berbeda terhadap giberelin untuk pembentukan jumlah lokul maupun plasenta. Dalam partenokarpi, hormon giberelin mencegah terbentuknya biji dengan menghambat proses fertilisasi. Pemberian hormone giberelin secara eksogen akan mencegah sampainya buluh serbuk sari ke celah mikropil pada ovarium dengan merusak dan menghambat perkembangan buluh serbuk sari. Akibatnya, sel sperma dan sel telur tidak dapat bertemu dan zigot tidak terbentuk. Jika zigot tidak terbentuk, maka perkembangan bakal biji akan terhenti (Wulandari et al., 2014). Seperti pada penelitian yang telah dilakukan, aplikasi berbagai konsentrasi hormon giberelin memberikan pengaruh nyata terhadap jumlah biji yang mana semakin besar konsentrasi hormon yang diberikan maka semakin kecil jumlah biji yang berada dalam buah mentimun. Pada Gambar 2 terlihat hubungan antara jumlah biji dan konsentrasi hormon giberilin berbentuk regresi linier dengan persamaan y 345.67 $-0.92 x$ dan nilai koefisien determinasi $R^{2} .90$

Biji dalam buah partenokarpi masih bisa terbentuk, hal ini membuktikan bahwa fertilisasi masih berlangsung meskipun tidak maksimal sehingga biji yang terbentuk pada buah partenokarpi memiliki ukuran yang lebih kecil dibandingkan buah hasil polinasi.

Selain itu tekstur biji juga memiliki tekstur yang lebih lunak. Sumardi (1993) mengemukakan bahwa stuktur biji terdiridari kulit yang berasal dari selaput bakal biji, tali pusar yang merupakan bagian yang menghubungkan biji dengan tembuni (tangkai biji), inti biji yang merupakan semua bagian biji disebelah dalam kulitnya yang terdiriatas embrio dan endosperm. 

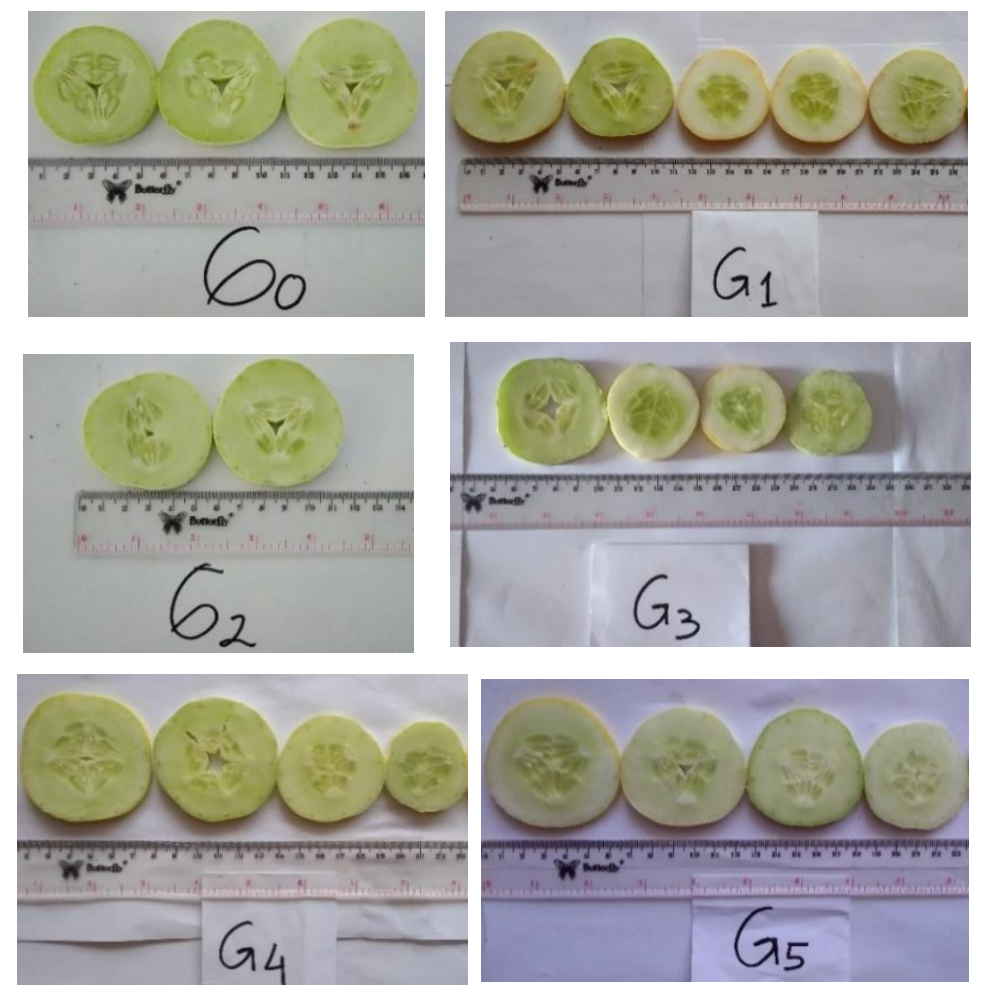

Gambar 1. Penampang melintang buah mentimun lokal Sumenep hasil polinasi dan partenokarpi menggunakan hormon giberelin

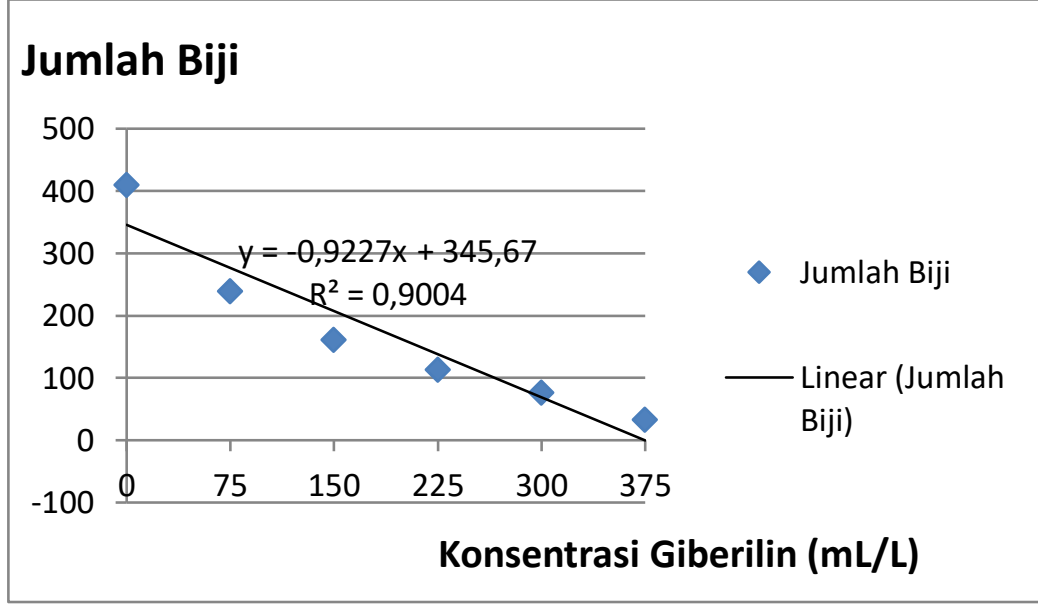

Gambar 2. Grafik hubungan Antara umlah Biji Mentimun dengan Berbagai Konsentrasi Giberilin 
Tabel 3. Rerata kadar air buah (\%), hardness $(\mathrm{g})$, fracturability $(\mathrm{g})$, gumminess, dan chewiness akibat aplikasi hormon giberelin $\left(\mathrm{GA}_{3}\right)$

\begin{tabular}{cccccc}
\hline \multirow{2}{*}{ Perlakuan } & Kadar Air Buah & \multicolumn{4}{c}{ Tekstur Buah } \\
\cline { 3 - 6 } & $(\%)$ & Hardness $(\mathrm{g})$ & Fracturability & Gumminess & Chewiness \\
\hline G0 & 96 & 572,18 & 621,01 & 34,74 & 7,51 \\
G1 & 97 & 583,32 & 610,54 & 34,26 & 7,31 \\
G2 & 97 & 580,54 & 609,64 & 34,42 & 6,98 \\
G3 & 97 & 583,05 & 616,68 & 35,62 & 7,25 \\
G4 & 96 & 579,00 & 614,46 & 35,96 & 7,04 \\
G5 & 96 & 580,95 & 572,90 & 34,14 & 7,12 \\
\hline BJND 5\% & ns & Ns & ns & ns & ns \\
\hline
\end{tabular}

Kesegaran buah dapat dilihat dari tingkat kadar air dan tekstur buah (Tabel 3) yang dapat berpengaruh pada daya simpan buah tersebut. Buah yang memiliki kadar air tinggi maka akan memiliki kekerasan buah yang rendah atau buah yang lebih lunak (Purwati, 2009 dalam Adnyesuari et al., 2015). Berdasarkan hasil analisis sidik ragam bahwa aplikasi hormon giberelin tidak berpengaruh nyata terhadap kadar air buah maupun tekstur buah mentimun lokal Sumenep. Kedua parameter ini saling berhubungan dimana kadar air buah yang semakin tinggi maka akan semakin rendah tingkat kekerasan buah yang juga akan berpengaruh terhadap kekenyalan, kealotan dan daya patah buah.

\section{KESIMPULAN DAN SARAN}

\section{Kesimpulan}

Berdasarkan penelitian yang telah dilakukan maka dapat disimpulkan bahwa aplikasi hormon giberelin terbukti mampu membantu pembentukan buah secara partenokarpi pada tanaman mentimun lokal Sumenep. Aplikasi hormon giberelin pada pembentukan buah secara partenokarpi tidak berpengaruh nyata terhadap parameter bobot buah, diameter buah, panjang buah, kadar air, dan tekstur buah. Namun berpengaruh nyata terhadap persentase keberhasilan buah, ketebalan daging buah dan jumlah biji per tanaman. Konsentrasi hormon giberelin terbaik adalah 300 ppm (G4) yang mengha-silkan buah dengan jumlah biji 81,5\% lebih sedikit dan ketebalan daging buah $16,9 \%$ lebih besar daripada buah hasil polinasi. Hubungan Antara jumlah biji dalam buah mentimun dan konsentrasi hormone gibrtilin tercermin dalam persamaan regresi linier $y=345.67-0.92 x$ dengan $\mathrm{R}^{2}=0.90$.

\section{Saran}

Sebaiknya aplikasi hormon giberelin dalam pembentukan buah secara partenokarpi di musim hujan dilakukan dengan cara semprot untuk mengoptimalkan hasil keberhasilan bunga jadi buah.

\section{DAFTAR PUSTAKA}

Adnyesuari, A. A., Murti, R. H., \& S. Mitrowihardjo.
(2015). Induksi Parteno-karpi pada Tiga Genotipe Tomat dengan GA3. Ilmu Pertanian,18(1), 56-62.

Badan Pusat Statistik. 2016. Sumenep dalam Angka2016. Katalog BPS. Sumenep.

Cong, B., Barrerro, L. S., \& Tanksley, S. D. (2008). Regulatory Change in YABBY- Like Transcription Factor LED to Evolution of Extreme Fruit Size during Tomato Domestication. J. Nature Genetics., 40, 800-804.

Griffiths, J., Murase, K., Rieu, I., Zentella, R., Zhang, Z. L., Powers, S. J., Gong, F., Phillips, A. L., Hedden, P. Sun, T. P., \& Thomas, S. G. (2006). Genetic Characteri-zation and Functional Analysis of the GID1 Gibberellin Receptors in Arabidopsis. Plant Cell, 18, 3399-3414.

Liu, S. \& Li, T. L. (2012). Regulation Effects of Exogenous Gibberellin Acid (GA3) on the Formation of Tomato (Solanum lycopersicum) Ovary Locule and Fascinated Transcription. African Journal Biotechnology, $11,13732-13738$

Pandolfini, T. (2009). Seedless Fruit Production by Hormonal Regulation of Fruit Set. J. Nutrient. 1(2), 168-177.

Pardal, S. J. (2001). Pembentukan Buah Parte-nokarpi Melalui Rekayasa Genetika. Buletin Agrobio, 4(2), 45-49.

Purwati, E. (2009). Daya Hasil Tomat Hibrida (F1) di Dataran Medium. J. Hortikultura, 19, 125-130.

Rukmana, R. (1994). Budidaya Mentimun. Kanisius. Yogyakarta.

Serrani, J. C., Fos, M., Atare's, A., \& Garci`amartu`nez, J. L. (2007). Effect of Gibberellin and Auxin on Partheno-carpic Fruit Growt Induction in the $\mathrm{Cv}$ Micro-tom of Tomato. J. Plant Growth Regul, 26, 211-221. 
Setiawan, A. B., Purwanto, A., \& Murti, R. H. (2015). Pengaruh Giberelin Ter-hadap Karakter Morfologi dan Hasil Buah Partenokarpi pada Tujuh Genotipe Tomat (Solanum lycopersicum L.). J. Ilmu Pertanian, 18(2), 69-76.

Sumardi, I. (1993). Struktur dan Perkembangan Tumbuhan. Universitas Gajah Mada. Yogyakarta.

Sumpena, U. (2001). Budidaya Mentimun Intensif, Dengan Mulsa, Secara Tumpang Gilir. Penebar Swadaya. Jakarta.

Widodo, W. D. (2002). Aktivitas Hormon Endogen dalam Buah Anggur Muscat of Alexandria Muda Tanpa Biji Hasil Induksi Antibiotika. Bul. Agronomi, 30(3), 9299.

Widyati, E. (2016). Peranan Fitohormon pada Pertumbuhan tanaman dan Implika-sinya Terhadap Pengelolaan Hutan. Galam BPPLH, 2(1), 11-22.
Wijayanto, T., Yani, W. O. R., \& Arsana, M. W. (2012). Respon Hasil dan Jumlah Biji Buah Semangka (Citrullus vulgaris) dengan Aplikasi Hormon Giberelin (GA3). J. Agroteknos., 2(1), 57-62.

Wulandari, D. C., Rahayu, Y. S., \& Ratnasari, E. (2014). Pengaruh Pemberian Hormon Giberelin Terhadap Pemben-tukan Buah secara Partenokarpi pada Tanaman Mentimun Varietas Mercy. LenteraBio, 3(1), 27-32.

Wulandari, D. C., Rahayu, Y. S., \& Ratnasari, E. (2014). Pengaruh Pemberian Hormon Giberelin Terhadap Pemben-tukan Buah secara Partenokarpi pada Tanaman Mentimun Varietas Mercy. LenteraBio, 3(1), 27-32.

Zulkarnain. (2010). Dasar-Dasar Hortikultura. Bumi Aksara. Jakarta. 